УДК 343.9

DOI https://doi.org/10.32849/2663-5313/2020.7.50

Тетяна Беркій,

аспірант кафедри кримінально-правових дисчиплін

Львівського державного університету внутрішніх справ

\title{
КРИМІНОЛОГІЧНА ХАРАКТЕРИСТИКА ЗАСОБІВ ПОПЕРЕДЖЕННЯ СЕПАРАТИЗМУ
}

У статті вивчено стан наукової розробки проблеми сепаратизму як правового та соціального явища. Дається кримінологічна характеристика засобів попередження сепаратизму в Україні. Зокрема, проаналізовано положення проекту Закону України «Про протидію $i$ запобігання сепаратизму та подолання наслідків сепаратистської діяльності на території Украӥни (десепаратизачію)». Окремо виділено принщип транскордонного співробітничтва як засіб запобігання сепаратистським настроям. Транскордонне співробітниитво не загрожує територіальній иілісності держави, воно регулює відносини сусідства на локальному або регіональному рівні між територіальними об'єднаннями. Вказується, що одностайності щодо дієвості чи, навпаки, шкідливості даного приниипу як засобу запобігання сепаратизму серед науковиів немає. Виокремлено новітній засіб запобігання та протидї сепаратизму, а саме сучасну стратегію запобігання злочинності (Модетп Crime Prevention Strategy), що розроблена у Великій Британї. Зокрема, йдеться про технологічне переоснащення поліиії. Одним з основних акцентів є максимальне використання можливостей Інтернету для забезпечення ефективної діяльності поліиї шляхом підвищення рівня комунікаціі між полічією і громадськістю. Проаналізовано правові засоби попередження сепаратизму. Зазначено, що натепер в українському законодавстві відсутня окрема стаття, яка б визначала сепаратизм як кримінально каране діяння та передбачала кримінальну відповідальність за такі дії. Поняття «сепаратизм» декілька разів згадується в підзаконних нормативно-правових актах у загальному значенні. 3'ясовано, що неабияку роль відіграє гуманітарна політика. Вона виступає основним фактором самоідентифікацї народу в умовах глобалізації та посилення загальної тендениї до мультикультурності. Станом натепер гуманітарна політика виступає надзвичайно важливим інструментом протидї зовнішнім і внутрішнім загрозам, зокрема таким, як прояви сепаратизму, зовнішня інтервениія, розмивання суверенітету держави, маніпулювання суспільною думкою, знищення національної ідентичності, роздмухування міжрегіональних, міжрелігійних та міжетнічних конфліктів. Наслідками діяльності сепаратистських рухів для гуманітарної безпеки Украӥни стала втрата ресурсів та необхідної інфраструктури для захисту і підтримання національного гуманітарного простору на частині територій.

Ключові слова: сепаратизм, запобігання злочинності, гуманітарна політика, десепаратизація транскордонне співробітництво, інформаційна безпека.

Постановка проблеми. Сепаратизм сьогодні являє собою одну з найбільш небезпечних загроз для всього світового порядку, а також актуальну проблему для розвитку науки державного управління як у теоретичному, так і практичному аспектах. Сепаратизм - поширене в сучасному світі суспільно-політичне явище, що притаманне багатьом поліетнічним державам, що являє собою серйозну загрозу як для України, так і для безлічі інших країн і територій світу. Проте залишається чимало неопрацьованих аспектів та дискусійних питань. Зокрема, і щодо засобів, методів, способів запобігання сепаратизму.

Аналіз останніх досліджень і публікацій з даної теми. Феномен сепаратизму перебуває в полі зору вітчизняної та зарубіжної наукової спільноти, їï різні аспекти досліджува- лися в працях українських (В. Багатиреєва М. Басараб, В. Горенкін, В. Дівак, І. Кресіна, С. Савойська) та зарубіжних (А. Баранов, І. Бочарников, Д. Горовиц, Р. Гріфіц, О. Крилов, Д. Сіроки) вчених та практиків [1, с. 2].

Зокрема, дослідженням питань, пов'язаних із сепаратизмом, у контексті філософських наук займалися такі вітчизняні вчені, як М. Вівчарик, К. Вітман, В. Горенкін, О. Картунов, А. Кіссе, В. Котигоренко, І. Кресіна, Л. Нагорна, О. Маруховська-Картунова, I. Оніщенко, Є. Перегуда, Г. Перепелиця, Ю. Римаренко, С. Римаренко, Л. Шкляр та інші. Не лишили поза увагою досліджуване явище також і західноєвропейські та американські науковці, такі як Р. Бербах, У. Робінсон, У. Бек, Дж. Келлас. Зокрема, в роботах останніх досліджується взаємозв’язок націоналізму і сепаратизму, 
умови та чинники реалізації права націй на самовизначення, причини негативного впливу сепаратизму на систему міжнародної безпеки, а також морально-етична проблематика сепаратизму [2, с. 148].

|| Метою даної наукової статті є кримінологічна характеристика засобів запобігання сепаратизму.

Виклад основного матеріалу. Запобігання злочинності - це здійснення спеціальними суб'єктами передбачених законом заходів для недопущення розвитку злочинного наміру на попередніх стадіях вчинення злочину, виявлення ознак скоєних злочинів, встановлення осіб, які їх скоїли, притягнення цих осіб до відповідальності, відновлення порушених прав, свобод і законних інтересів громадян та відшкодування збитків від злочинних дій [3].

Важливим завданням держави на даному етапі є формування стратегії протидії сепаратизму в Україні, яка має базуватися на глибокому аналізі причин цього явища і можливостей держави щодо протидії [4, с. 18].

Так, у проєкті Закону України «Про протидію і запобігання сепаратизму та подолання наслідків сепаратистської діяльності на території України (десепаратизацію)» визначаються правові та організаційні засади протидії сепаратизму на основі реалізації системи заходів зі звільнення державного, суспільно-політичного, економічного та гуманітарного життя України від проявів сепаратизму, подолання наслідків сепаратистської діяльності на всій території України та запобігання загрозам сепаратизму в майбутньому. У ст. 3 проекту цього закону розкривається суть поняття десепаритазації. Так, під десепаратизацією в цьому Законі розуміється комплекс заходів, що здійснюються з метою звільнення органів законодавчої, виконавчої, судової влади, правоохоронних органів, Збройних Сил України, Служби безпеки України, органів місцевого самоврядування, політичних партій та громадських об'єднань, вищих навчальних закладів, засобів масової інформації, підприємств, установ і організації усіх форм власності від будьяких проявів сепаратизму та запобігання загрозам сепаратизму в майбутньому. Десепаратизація в Україні спрямована на забезпечення територіальної цілісності України, недоторканності іiі державних кордонів, зміцнення єдності та незалежної державності України, гарантування права громадян України жити у вільній суверенній державі. Досягнення мети десепаратизації базується на комплексній реалізації державою люстра- ційних, ліквідаційних, конфіскаційних, освітніх та інформаційнихзаходів [5].

Кандидат політичних наук, доцент Є. В. Рябінін, виділяє як один із засобів запобігання сепаратистським настроям транскордонне співробітництво. Треба відзначити, що у вітчизняній і зарубіжній літературі під транскордонним співробітництвом, як правило, розуміють спільні дії, спрямовані на посилення і розвиток добросусідських відносин між територіальними органами влади прикордонних держав, які реалізуються шляхом укладання міжрегіональних угод і домовленостей. Транскордонне співробітництво не загрожує територіальній цілісності держави, воно регулює відносини сусідства на локальному або регіональному рівні між територіальними об'єднаннями.

Суть принципу транскордонного співробітництва полягає у тому, що це дає шанс так званим розділеним регіонам. У свою чергу, український вчений Олена Кривицька у своїй роботі «Демаркаційні лінії в етнополітичному просторі України» висловлює думку про негативні наслідки транскордонного співробітництва. Аналізуючи транскордонне співробітництво між регіонами України та Румунії, авторка вважає, що транскордонну співпрацю можна оцінити як своєрідний механізм контролю Румунією дотримання етнокультурних прав румунської меншини.

Таким чином, одностайності щодо дієвості чи, навпаки, шкідливості даного засобу запобігання сепаратизму серед науковців немає. Прихильники ж цього засобу стверджують, що транскордонне співробітництво здатне знизити градус невдоволення етнічної групи, яка розділена кордоном, та може сприяти збереженню територіальної цілісності держави і мирного співіснування різних етнічних груп [6].

Сьогодні виділяють ще один новітній метод, засіб запобігання злочинності, в тому числі сепаратизму. Так, сучасна стратегія запобігання злочинності (Modern Crime Prevention Strategy), що розроблена у Великій Британії, містить розділ, присвячений використанню даних та технологій для цієї діяльності (Using Data and Technology to Prevent Crime). За основу взяті такі напрями: технологічне переоснащення поліції, підвищення рівня кваліфікації співробітників, тісна співпраця, партнерство з громадськістю щодо запобігання злочинності. Зокрема, одним 3 основних акцентів $є$ максимальне використання можливостей Інтернету для забезпечення ефективної діяльності поліції шляхом підвищення рівня комунікації між поліцією і громадськістю. Загалом сутність 
удосконалення запобіжної діяльності поліції на перспективу можна охарактеризувати як підвищення рівня інтелектуального впливу на цей процес, залучення сучасних інтернеттехнологій для збору, аналізу та зберігання даних, а також кримінологічного прогнозування [7, с. 147].

Поширення сепаратистських настроїв в Інтернеті є досить поширеним явищем. За результатами проведених досліджень виникнення інформаційних та інформаційно-психологічних загроз, які можуть бути реалізовані за допомогою соціальних мереж в Інтернеті, науковці зазначили, що за допомогою соціальних мереж в Інтернеті можливе таке:

- створення атмосфери бездуховності та аморальності, негативного ставлення до культурної спадщини; маніпулювання суспільною свідомістю і політичною орієнтацією соціальних груп населення країни 3 метою створення політичної напруженості та хаосу;

- дестабілізація політичних відносин між партіями, об'єднаннями і рухами з метою провокації конфліктів, розпалення недовіри, підозрілості, загострення політичної боротьби, провокування репресій проти опозиції, провокація;

- зниження рівня інформаційного забезпечення органів влади та управління, інспірація помилкових управлінських рішень;

- дезінформація населення про роботу державних органів, підрив їхнього авторитету, дискредитація органів управління;

- провокування соціальних, політичних, національних та релігійних зіткнень; ініціювання страйків, масових заворушень та інших акцій економічного протесту;

- утруднення прийняття органами управління важливих рішень;

- підрив міжнародного авторитету держави, її співробітництва з іншими країнами;

- нанесення шкоди життєво важливим інтересам держави в політичній, економічній, оборонній та інших сферах.

Одним із перших суттєвих кроків було посилення уваги з боку держави до діяльності соціальних мереж в Інтернеті, а саме підписання Президентом України Указу № 133/2017. Указом було введено обмежувальні санкції щодо соціальних мереж «Vk.com», «Odnoklassniki.ru» та інших, а провайдерів 3 надання послуг Інтернету зобов'язали блокувати на системному рівні можливості входження до даних соціальних мереж. Водночас така увага не повинна порушувати прав людини, що зафіксовані у законодавстві [8].

Крім того, для захисту інформаційної безпеки на території України було заборонено трансляцію російських каналів в ефірних і кабельних мережах («Первый канал. Всемирная сеть», «РТР-Планета», «НТВ-Мир», «Россия-24», «TVCI», «Россия-1», НТВ ТНТ, «Петербург-5», «Звезда», «Рен-ТВ» i «РБК-ТВ», а також «Life News» та «Russia Today» як неадаптовані), які поширюють ідеї сепаратизму та антиукраїнську пропаганду. Офіційною причиною рішення Національної ради з питань телебачення й радіомовлення України про заборону ретрансляції російських каналів стала суперечність змісту їх програм Конституції України та необхідність адаптації до законодавства України. Нагляд за дотриманням рішення про їх відключення здійснює МВС [9, с. 191].

Неабияке значення мають правові засоби попередження сепаратизму в Україні. Проте станом на сьогодні законодавство в Україні не містить визначення поняття «сепаратизм», що певною мірою ускладнює формування та реалізацію державної політики у сфері протидії цьому суспільно небезпечному явищу. Проте чинним Кримінальним кодексом України встановлено кримінальну відповідальність за суспільно небезпечні діяння, які містять у собі прояви (ознаки) сепаратизму. Йдеться, зокрема, про посягання на територіальну цілісність і недоторканність України (стаття 110); фінансування дій, вчинених з метою насильницької зміни чи повалення конституційного ладу або захоплення державної влади, зміни меж території або державного кордону України (стаття 110-2) [4, с. 21].

Проте в українському законодавстві всетаки $є$ ряд нормативно-правових та підзаконних актів, де згадується поняття «сепаратизм».

Наприклад, Постанова Верховної ради України «Про запобігання проявам сепаратизму та іншим посяганням на основи національної безпеки України» від 22 лютого 2014 р. № 756-VII, Указ Президента України від 26 травня 2015 р. № 287/2015 «Про рішення Ради національної безпеки і оборони України від 6 травня 2015 р. "Про Стратегію національної безпеки України”», Указ Президента України «Про рішення Ради національної безпеки і оборони України від 2 вересня 2015 р. "Про нову редакцію Воєнної доктрини України"» від 24 вересня 2015 р. № 555/2015, Указ Президента України «Про Концепцію державної мовної політики» від 15 лютого 2010 р. № 161/2010 [1].

Проте в кримінальному законодавстві України відсутня спеціальна норма, яка б встановлювала відповідальність за вчинення сепаратистських дій на території України. 3 приводу цього професор В. П. Ємельянов 
пропонує запозичити позитивний досвід Республіки Казахстан та доповнити Розділ I Особливої частини Кримінального кодексу України статтями, які би передбачали кримінальну відповідальність за сепаратистську діяльність та збройний заколот [10, с. 103].

К. О. Литвиненко у своєму дисертаційному дослідженні на тему «Гуманітарні чинники генерування сепаратистських рухів в Україні» зазначає, що гуманітарна політика держави виступає важливим фактором самоідентифікації народу в умовах глобалізації та посилення загальної тенденції до мультикультурності. Станом на сьогодні гуманітарна політика виступає надзвичайно важливим інструментом протидії зовнішнім і внутрішнім загрозам, зокрема таким, як прояви сепаратизму, зовнішня інтервенція, розмивання суверенітету держави, маніпулювання суспільною думкою, знищення національної ідентичності, роздмухування міжрегіональних, міжрелігійних та міжетнічних конфліктів тощо. Гуманітарна безпека як складова частина національно безпеки може бути визначена як ступінь захищеності життєво важливих інтересів суспільних і політичних суб'єктів, що визначаються їхніми специфічними світоглядноціннісними орієнтаціями. Основною метою гуманітарної безпеки $€$ захист цілісності i сталого функціонування національного гуманітарного простору, а також захист громадян, груп і держави в цілому від негативних зовнішніх впливів гуманітарного характеру. Національний гуманітарний простір може бути визначений як середовище, в якому виробляється та функціонує система ідей, цінностей, ідеалів, міфів, стереотипів, образів, що впливають на свідомість людей i, таким чином, визначають напрями поступу нації та держави. Суб'єктами впливу на національний гуманітарний простір можуть бути різноманітні внутрішні і зовнішні державні і недержавні актори. Технологія так званих «гібридних війн» приділяє велику увагу впливу гуманітарного характеру на супротивника, зокрема інформаційнопсихологічному впливу та іншим засобам «м'якої сили». Наслідками діяльності сепаратистських рухів для гуманітарної безпеки України стала втрата ресурсів та необхідної інфраструктури для захисту і підтримання національного гуманітарного простору на частині територій, існування перешкод для захисту від інформаційного впливу супротивника жителів окупованих районів, поглиблення суперечностей в українському суспільстві, радикалізація певної його частини, створення умов для маніпулювання патріотизмом та національною ідеєю, активізація діяльності популістських антивоєнних проросійських рухів тощо.

Разом із тим загроза суверенітету і майбутньому існуванню України є мотивуючим фактором для вдосконалення системи гуманітарної безпеки та реформування гуманітарної політики для консолідації суспільства, вироблення загальноукраїнської ідентичності, цінностей та формування політичної нації. Для подолання наслідків діяльності сепаратистських рухів та запобігання ix генеруванню у майбутньому доцільним $€$ використання засобів гуманітарної політики [11. с. 169-170].

3 огляду на останні зміни, які відбуваються у світі, швидкість поширення сепаратистських настроїв, існує нагальна необхідність у розробці дієвих способів та засобів запобігання та протидії цьому явищу.

\section{Висновки}

Підбиваючи підсумок викладеного, слід зазначити, що незважаючи на різноманіття наукових доробок та розробок, які стосуються вивчення явища сепаратизму, проблема запобігання цьому явищу і досі залишається актуальною. В Україні проблема запобігання сепаратизму на законодавчому рівні не вирішена взагалі. Адже з основних законодавчих доробок у нас є лише проєкт Закону України «Про протидію і запобігання сепаратизму та подолання наслідків сепаратистської діяльності на території України (десепаратизацію)». Досягнення мети десепаратизації базується на комплексній реалізації державою люстраційних, ліквідаційних, конфіскаційних, освітніх та інформаційних заходів.

Проте, у зв'язку з науково-технічним прогресом, який відбувається ніби за геометричною прогресією, необхідно розробляти дієві засоби протидії та запобігання сепаратизму i в кібернетичній сфері. Зокрема, йдеться про удосконалення технологічних заходів та засобів для запобігання злочинності, в тому числі і сепаратизму, з використанням можливостей Інтернету. Крім цього, всетаки важливим і необхідним є закріплення на законодавчому рівні визначення поняття сепаратизму та дій, які підпадатимуть під його ознаки, а також встановлення санкцій за вчинення таких дій. Це дасть змогу виробити дієвий, цілісний механізм запобігання сепаратистським настроям.

\section{Список використаних джерел:}

1. Сталенна Л. С. Регулювання правових відносин щодо протидії сепаратизму в Україні. Теорія та практика державного управ- 
ління. 2015. Вип. 4.. 69-76. URL: http://nbuv.gov. ua/UJRN/Tpdu_2015 4_13 (дата звернення: 17.06.2020).

2. Литвиненко К.О. Сепаратизм як предмет соціальної і політичної філософії. International Scientific Journal. 2015. № 6 (12). URL: http://fundissled-intern.esrae.ru/pdf/2015/6(11)/237.pdf (дата звернення: 17.06.2020).

3. Вісник кримінологічної ситуації України URL: https://visnikkau.webnode.com.ua/news/ protidiya-zlochinnosti/ (дата звернення: 17.06.2020).

4. Резнікова О. О., Дрьомов С. В. Деякі законодавчі аспекти протидії сепаратизму в Україні. Стратегічні пріоритети. 2016. № 3. C. 18-25. URL: http://nbuv.gov.ua/UJRN/spa_2016_3_5 (дата звернення: 17.06.2020).

5. Проект Закону України «Про протидію і запобігання сепаратизму та подолання наслідків сепаратистської діяльності на території України (десепаратизацію)» від 17.07.2014 № 4300a. URL: http://w1.c1.rada.gov.ua/pls/zweb2/webproc4_2 $? \mathrm{id}=\& \mathrm{pf} 3516=4300 \% \mathrm{E} 0 \& \mathrm{skl}=8$ (дата звернення: 17.06.2020).

6. Рябнін Є.В. Транскордонне співробітництво як механізм попередження сепаратистських конфліктів. URL: http://mdu.in.ua/Novosti2/9/ zbirnik 2017.pdf\#page=152 (дата звернення: 17.06.2020).
7. Бугера О.І. Сучасні кримінологічні стратегії запобігання злочинності 3 використанням мережі інтернет: зарубіжний досвід. Підприємниитво, господарство і право. 2019. № 1. C. 146-149. URL http://pgp-journal.kiev.ua/archive/2019/1/28.pdf (дата звернення: 17.06.2020).

8. Соціальні мережі в Інтернеті як інструмент загрозі національній системі кібербезпеки України. URL: http://academy.ssu.gov.ua/upload/file/ aktualn_problemi_upravl_nnya_nformac_ycnoyu bezpekoyu derzhavi.pdf\#-̄age $=\overline{9} 0$ (дата звернення: 19.06.2020).

9. Кресіна І. О., Коваленко А. А. Ситуативні механізми протидії сепаратизму в Україні: політико-правовий аналіз. Держава і право. Юридичні і політичні науки. 2014. Вип. 65. С. 291-299. URL http://nbuv.gov.ua/UJRN/dip_2014_65_43 (дата звернення: 19.06.2020)

10. Руфанова В. М. Нормативно-правове забезпечення протидії сепаратизму в Україні. Haше право. 2016. № 2. C. 101-106. URL: http:// nbuv.gov.ua/UJRN/Nashp_2016_2_19 (дата звернення: 19.06.2020).

11. Литвиненко К. О Гуманітарні чинники генерування сепаратистських рухів в Україні : дис. ... канд. філософ. наук: 21.03.01. Київ, 2018. URL http://old2.niss.gov.ua/public/File/20219_01_02/ dis_Lytvynenko.pdf (дата звернення: 19.06.2020).

Tatiana Berkii. Criminological characteristics of means of prevention of separatism

The article examines the state of scientific development of the problem of separatism as a legal and social phenomenon. The criminological characteristic of means of prevention of separatism in Ukraine is given. In particular, the provisions of the draft Law of Ukraine "On Counteracting and Preventing Separatism and Overcoming the Consequences of Separatist Activities on the Territory of Ukraine (Deseparatization)" were analyzed. The principle of cross-border cooperation as a means of preventing separatist sentiments is singled out. Cross-border cooperation does not threaten the territorial integrity of the state, it regulates the relations of neighborhood at the local or regional level between territorial associations. It is pointed out that there is no unanimity among scholars about the effectiveness or, on the contrary, the harmfulness of this principle as a means of preventing separatism. The latest means of preventing and combating separatism, namely the Modern Crime Prevention Strategy, developed in the UK, has been identified. In particular, it is a question of technological re-equipment of police. One of the main emphases is to make the most of the Internet to ensure effective policing by improving communication between the police and the public. The legal means of preventing separatism are analyzed. It is noted that today in the Ukrainian legislation there is no separate article that would define separatism as a criminally punishable act and provide for criminal liability for such actions. The concept of "separatism" is mentioned several times in bylawes in the general sense. Humanitarian policy has been shown to play an important role. It is a major factor in the self-identification of the people in the context of globalization and the strengthening of the general trend towards multiculturalism. Today, humanitarian policy is an extremely important tool for combating external and internal threats, such as separatism, foreign intervention, erosion of state sovereignty, manipulation of public opinion, destruction of national identity, incitement of interregional, interreligious and interfaith. The consequences of the activities of separatist movements for the humanitarian security of Ukraine were the loss of resources and the necessary infrastructure to protect and maintain the national humanitarian space in some areas.

Key words: separatism, crime prevention, humanitarian policy, deseparation, cross-border cooperation, information security. 